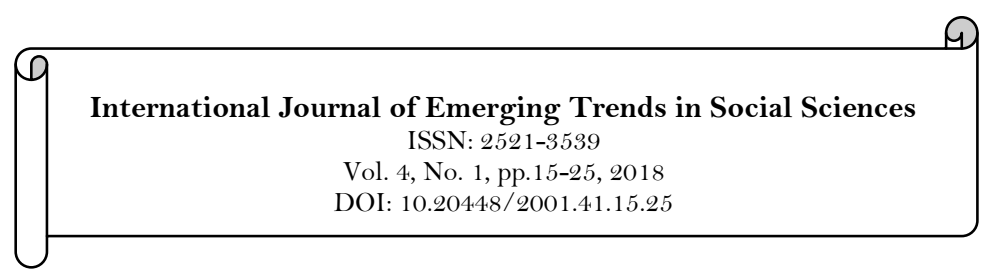

\title{
Review of Impacts of Leadership Competence of Project Managers on Construction Project Success
}

\author{
Thi Phuong Thao $\mathrm{Ha}^{1}$ \\ Manh Dung $\operatorname{Tran}^{2 \mathbf{s}}$ \\ ${ }^{1}$ University of Labor and Social Affairs, Vietnam. \\ ${ }^{2}$ National Economics University, Vietnam. \\ Email:manhdung@ktpt.edu.vn
}

\begin{abstract}
Leadership - Human endeavors play an important role in all areas of socio-economic development for any country in the world. Construction investment projects need more leadership role by their own characteristics. This research aims to give an overview of the theories of project manager leadership competence, the viewpoints of evaluation of the project's success, and the views on the influence of leadership competences and the success of the project. Research on the use of reliable secondary document sources in the world is synthesized from research works, scientific reports in the field of project management. The results of this study show that there is a great deal of research literature on project manager leadership competence and the success of the project in general but not many research papers on construction projects. This research is intended to suggest further studies to determine the specific influences, from that the training direction will increase the project management competence in the field of construction.
\end{abstract}

\author{
Keywords: \\ Leadership \\ Competence \\ Success \\ Project manager \\ Construction. \\ Licensed: \\ This work is licensed under a \\ Creative Commons Attribution \\ 4.0 License. \\ Publisher: \\ Scientific Publishing Institute
}

\section{Introduction}

In the context of the changing business environment, the constant advancement of science and technology, the competitive pressure tends to increase, this is the reason organizations are nowadays increasingly using more projects to achieve goals or increase competitive advantage in the market and thus the improvement of the efficiency of project management becomes necessary, especially in construction project investment activities.

Antoine de Saint-Exupéry conveyed the true nature of the leadership by saying, "If you want to build a ship, do not call people to get timber, do not give them the task and work, but Let teach them know the longing for the vastness of the sea.

Most of the authors on leadership topics find it difficult to address the differences between leadership in the organization and leadership in projects as the project leadership face more challenging due to the unique and temporary nature of the projects.

Leadership - Human endeavors play an important role in all areas of socio-economic development for any country in the world. Construction investment projects will need more leadership role as projects require hightech, large-scale, diversified, influenced by the external environment, long construction process and involves a large number of discrete work groups but closely correlate.

Construction products, services that affect long-term socio-economic development in developing countries, the implementation of successful projects are meaning for each country and people. So in the construction industry, effective project leadership is even more urgent. Some argue that effective leadership is one of the main answers to the problems of the construction industry, especially for issues in developing countries.

According to the guidelines on basic knowledge in project management of project management institute (PMI) Guidelines: Project management is the application of knowledge, skills, tools and techniques to project management activities aiming to achieve the set objectives.

Projects are formed and accomplished by gathering people, participating in the whole process of achieving the goal. Therefore, the project manager must be a good leader to lead the project team / team to work 
effectively in the limited resources and the ever-changing environment. The project leader must be the one who sets the goals in an effort and influences everyone to follow. It is important for the project manager to have the necessary leadership capacity to form and facilitate a project team implementing their works to accomplish the project goals.

Project management over a long period of time is seen as a technical field, and good project managers in any situation must strive to achieve the highest results in terms of time, quality and cost.

In recent times, project management theorists in the world have suggested that different projects in the construction industry may require methods, processes and technologies, but above all the need to choose a qualified project manager who meets the specific requirements of the implemented project.

The success of individual projects is a key factor determining the success of the organization, according to Murphy, Baker, and Fisher (1974); (Morris, 1988; Pinto \& Slevin, 1989). In recent years, many studies have investigated the clear link between project manager leadership competence and project success, namely (Crawford, 2005; Geoghegan \& Dulewicz, 2008; Müller \& Turner, 2007b).

Therefore, the study of this topic overall to give a picture including elements with different shades of light such as leadership capability of project managers, the success of the construction project and their influence is extremely necessary to directing research results in this field in the future.

\section{Overview of Studies on Leadership Competence of Project Managers 2.1. Leadership Competence}

In the Oxford English Dictionary, the word "competence" consists of two synonyms, such as competence and competency, which are interpreted as follows: (i) the ability to do something successful or effective; (ii) jurisdiction, legal competence (of the court, judge, etc.); (iii) Enough means to live in an easy situation.

Woodruffe (1991) shows that competence is used to refer to two factors: a) ability to be proven to perform work fluently; b) the set of behaviors that the person must present to perform the tasks and functions of the competent work.

Moore, Cheng, and Dainty (2002) proposed the following characteristics of key terms: (i) Authorization: Scope of work; (ii) Competence: Aids to perform tasks within authorization; and (iii) Competence: The attributes that underlie a behavior.

Armstrong (1996) gives another example to find the difference between "competence" and "competency." Armstrong's view is "authorization" that describes what people need to be able to do to do the job well; Emphasis on "do" (achieving desired results).

The word "competence" in turn has defined the contents regarding the size of the behavior behind the competent performance. This is often called behavioral competence, because they are used to describe how people behave when they work. The term "competence", along with the terms of authorization and ability, reflects the recognition of an expert's ability level deriving from having some related attributes such as knowledge, skills and attitude; often referred to as competence.

According to Boyatzis (1982) competence is a fundamental characteristic of a person who results in effective action and / or high performance at work. This concept is controversial because it really refers to "behavior" ("competence") or "attribute" (competence).

Armstrong (1996) defines competence as "not the task of the job, they are what allows people to do the task". Therefore, personal qualities are at the center of this approach. According to Chawla, Khanna, and Chen (2010) competence is called as "human's basic characteristics that show behavior or thinking, generalizing on many situations and surviving for a long time".

Competence is "one of the basic characteristics of a person leading to efficiency and / or high efficiency", meaning that different people will have different basic characteristics and thus lead to different successes (Boyatziss, 1998). The term "basic character" referring to qualities is deep traits of a person who can predict behavior in a variety of situations (Spencer \& Spencer, 1993).

The "upstart" idea schools on leadership regard leadership as a combination of individual characteristics and competence aspects. In other words, it is a combination of skills and knowledge, such as empowerment and achievement, along with personal characteristics such as intuition, they make a leader. Bass (1985) is a person who has a great influence on the theory of leadership.

Returning to personal traits, Hogan and Hogan (2002) finds that the personality of the leader is a determinant of effectiveness because he believes skills are based on personality traits. It is a combination of character and ability that can create different leaders in accordance with different situations: the leaders transferred in a time of low complex environment and the leaders transferred in a time of increased complexity. This is similar to Bass (1990) claim that certain leaders are better suited to stable environments, while others are better suited to a rapidly changing environment.

Geoghegan and Dulewicz (2008) argue that the combination of personality and competence is highly subject to personal and there is no clear definition of this. Leadership competence can be traits, motives, attitudes or values, self-awareness, knowledge, skills, behavior or awareness of any individual. 
Qualities can be measured reliably and can show significant differences between senior and middle managers (Spencere, 1994).

\subsection{Leadership Competence of Project Manager}

The trend is that the role of the project manager is changing from a focus on management to leadership, to lead project successfully requiring essential skills and leadership ability. Sotiriou and Wittmer (2001) note that although general leadership has been the focus of research for more than a hundred years, empirical research is relatively less focused on project leadership.

Project managers face the complexities of the project such as size, project impacts to other organizations, number of relating partners, personnel involved in the project, limitations on time, cost, uncertainty, or project outcome criteria must be met at the outset.

Several studies have identified the competence associated with project managers. Rees, Turner, and Tampoe (1996) identified six characteristics of effective project managers and asserted that effective managers often had above average intelligence and good problem solving ability.

These characteristics are similar to Intelligence Quotient (IQ) that Dulewicz and Higgs (2005) call a part of their leadership competence. Other characteristics identified by Rees and his colleagues are behavioral or motivational characteristics, such as competence and characteristics based on skills, for example communication. Andersen, Grude, Haug, and Turner (1987) recognize the importance of the individual characteristics of the project manager when selecting a project manager such as creative capacity. This view is similar to that of Hogan and Hogan (2002) who found that the personality of a leader is a determinant of effectiveness.

Pintop and Prescott (1988) recognized the characteristics of an effective project leader: credibility, problem solving, creativity, ambiguity pressure, flexible management style, and effective communication. They also identify the skills needed for project managers: technical skills, administrative skills (making plans, budgets, etc.) and leadership skills (vision, set examples). These skills would create a good project manager, however, again, Pintop and Prescott (1988) did not explicitly link those characteristics and skills to the success of the project.

Based on the literature on the competence of the project manager, it can be affirmed that the required competence for project managers in today's organizations are not the same as those that have been hit before. It is recognized that an effective project manager will possess a combination of personal characteristics, such as flexibility and capabilities, for instance problem solving - unlike the school of thinking about emerging leadership was discussed earlier.

However, up to now, the literature has not yet indicated a direct link between the project manager's leadership ability and the success of the project. Is project leadership not considered as an important factor in successful project implementation?

According to Crawfordp (2007) project manager's leadership competence is a combination of knowledge (ability to work), knowledge (qualification), and core personality traits (motives, traits, and concepts) leading to high results. Geoghegan and Dulewicz (2008) acknowledge that so far the theory has not proven that existence of a direct link between the manager's leadership capacity and the success of the project.

Crawfordp (2007) points out that the competence of project managers and project successes is closely linked and that the competence of the project manager is a factor to successfully distribute the projects. The role of the project manager is developing rapidly from the management or direction to lead the project with essential leadership skills and competences.

The impact of project leadership ability on project success has been ignored in most project management studies. Few studies, however, underline the importance of leadership ability of project managers in project management success (Geoghegan \& Dulewicz, 2008).

Competence is a group of factors including: relevant knowledge, skills, attitudes, and other personal characteristics that can be measured against well-accepted standards that can be improved through training and developing. Competence can affect a large part of the work, relative to work performance, and can be divided into different levels of competence. "(Limsila \& Ogunlana, 2008).

Based on theoretical studies of Dulewicz and Higgs (2005); (Müller \& Turner, 2007a; Müller \& Turner, 2010a) this study synthesizes the leadership competences in the context of project management is shown in Table 1. 
Table-1. Leadership competence in the context of project management.

\begin{tabular}{l|l}
\hline Competence & Assessment \\
\hline IQ (intellectual quotation) & - Strategic thinking \\
& - Vision and imagination \\
& - Ability to analyze judgment \\
\hline MQ (management quotation) & - Resource management \\
& - Target Management \\
& - Empowerment \\
& - Develop \\
& - Connecting communication \\
\hline EQ (emotion quotation) & - Self-awareness \\
& - emotional restoration \\
& - Ability to intuition \\
& - Sensitive \\
& - Create influence \\
& - Motivation \\
& - Devotion \\
\hline
\end{tabular}

Source: Dulewicz and Higgs (2005).

\subsection{Leadership Competence of Project Managers in Construction Industry}

Leadership is a key factor to success in any activity that involves collaboration between working groups (or group) of people. In construction, leadership is essential, this has been established in many studies (Long, Ogunlana, \& Lan, 2004; Odusami, 2002). Thamhain (2003) emphasized the importance of leadership to create a supportive working environment for the project participants. Munns and Bjeirmi (1996) emphasize that success or failure in project management is highly dependent on project leaders.

Although there are many studies that recognize important leadership role at all management levels in the construction industry but this industry remains more focused on the technical aspects as well as management and leadership role is negligibly interested (Skipper \& Bell, 2006a).

Songer, Chinowsky, and Butler (2006) highlight some of the current and future building industry leadership challenges. Toors and Ofori (2008) list emerging leadership challenges, including sector-specific challenges, in general for businesses and in the operating environment. For example, some surveys show that interviewee in the construction industry are unsatisfied with the morality and authenticity of the leader (Toor \& Ofori, 2007).

Toor and Ogunlana (2008a) found that the major problems faced by construction projects in Thailand included an incomplete procurement system, inadequate resources, the difference between design and construction, inadequate project management practices, order management, imposition, ineffective communication, cultural issues, and differences in participants' interests.

In Malaysia, Abdul-Rahman, Rahim, Danuri, and Low (2007) shows that management quality is not satisfactory for contractors undertaking public design and construction projects. Quality relating factors that contribute to this situation are budget constraints, time constraints, customer complexity, poor communication and design changes.

\section{Overview of Success of Construction Project \\ 3.1. Overall Project Success}

Identifying the concept of project success will facilitate understanding of research requirements. Although the project's success has been a major concern and has been written and spoken quite a lot to this phrase (Cooke-Davies, 2002) but the concept of project success is still very broad and vague (Al-Tmeemy, AbdulRahman, \& Harun, 2011; Chan, Scott, \& Chan, 2004).

In addition, much of the theory has proven that the project's success is a multidimensional concept (eg, (Al-Tmeemy et al., 2011; Atkinson, 1999; Shenhar \& Wideman, 1996)). In addition, the theme of the project's success is more complex when applied in many industries, construction, information technology and defense industries (Abdullah, 2010).

The view of management field, the success of the project is a strategic concept in which the objectives of the project must be aligned directly with the organization's short-term and long-term goals (Al-Tmeemy et al., 2011).

The success of the project can actually be classified into two categories: either the criteria for assessing the success of the project (or level) or critical success factors (CSFs) have been explored for several decades. Furthermore, according to Abdullah (2010) success criteria are defined as a set of "principles or standards used to determine or evaluate the success of the project and important success factors refer more specifically to the conditions, situations and circumstances that contribute to the outcome of the project.

According to Müller and Jugdev (2012) the success factors of a project are defined as the factors of the project being affected will increase the likelihood of success, as independent variables. On the other hand, the 
success criteria of a project are dependent variables that measure the success or failure of a project. It is interesting to note that in a project environment, the criteria for success can be called "what is achieved" and in the meantime, the success factor can be called "how to achieve "(Abdullah, 2010).

The success of the project has different meanings for different people. Each industry, project group or individual has a successful definition. Parfitt and Sanvido (1993) view success as an sense of intangible photosensitivity,

A measurement standard changes according to the expectations of management and change between people and the stages of the project. In fact, owners, designers, consultants, contractors as well as subcontractors have the goal and criteria of the project to measure success. For example, architects may view aesthetics or function as the main criterion rather than the cost of construction, while the customer may have a view of comfort, security. Furthermore, even the perception of success of everybody is also changing from this project to other one. The definition of project success can vary by project type, size, sophistication, project participant, and owner experience, etc.

Golden Triangle refers to time, cost and quality as a traditional success criterion, and this is not enough (Bakhsheshi \& Nejad, 2011). Long et al. (2004) identified six measures for project implementation including budget performance, performance schedule, quality, owner satisfaction, profitability, public satisfaction.

During the in-depth review process of the project management documents, Freeman and Beale (1992) have identified some success criteria for projects, the most commonly used of which are technical quality, performance, organizational and managerial outcomes, personal development and manufacturing capabilities and business performance.

Jugdev and Muller (2005) outline effectively the trends associated with the success in project management in Figure 1. Figure 1 shows that stages 1 and 2 focus primarily on success in relation to life cycle of the project.

In phase 3 more comprehensive success factors were developed, but what is expected is similar to phase 4 where the success of the project is assessed with the contribution of relating partners and throughout the stages of the project extending to the product life cycle. It is therefore only logical that the success of the project is no longer focused on the project itself, but evolve in a broader direction including the views of the organizations and relating partners, customer satisfaction, strategic goals, value creation, team development, knowledge management, continuous improvement and also environment.

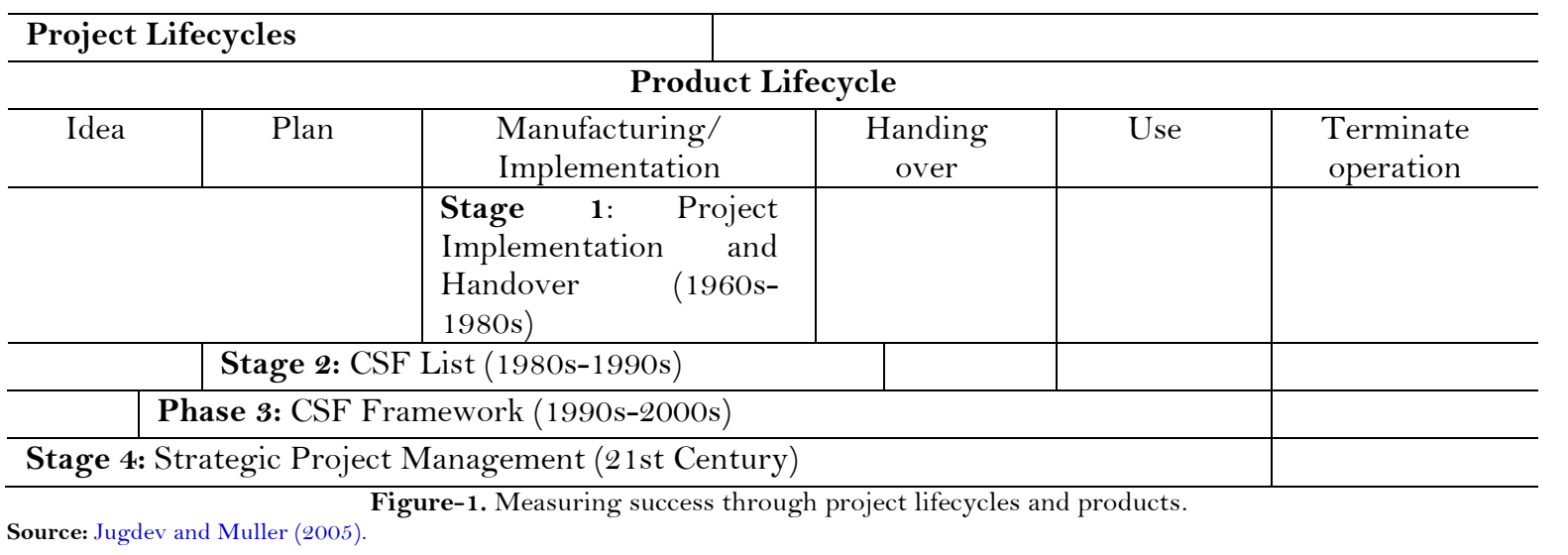

This view is clearly shown in the studies of Shenhar, Dvir, Levy, and Maltz (2001) in which the authors shifted from the traditional viewpoint on the project's success criteria to a broader framework that suitable for the complexity of today's project management environment. They identified four key success areas - project effectiveness, impact on customers, direct sales, organizational success, and future preparedness.

Müller and Turner (2007b) also conducted in-depth studies of success criteria from the perspective of project managers and have decided to add to the list of successful criteria. According to Jugdev and Muller (2005) criteria of success of the project as (i) Satisfied end users; (ii) Satisfied provider; (iii) Satisfy the team; (iv) Satisfying shareholders to contribute shares; (v) Efficiency in time, price, quality; (vi) Meet the requirements of consumers; (vii) Project achieved objectives; (viii) Customer Satisfaction; (ix) Frequent exchanges; and (x) Identify personal goals. 
Table-2. Success Factors.

\begin{tabular}{l|l}
\hline Success Factors & Evaluation Criteria \\
\hline 1. Efficiency of the project & $\begin{array}{l}\text { Meet the goal of progress } \\
\text { Meet budget goals }\end{array}$ \\
\hline 2. Impact on customers & $\begin{array}{l}\text { Meet the requirement for active features } \\
\text { Meet technical standards } \\
\text { Meet the requirements of customers } \\
\end{array}$ \\
& $\begin{array}{l}\text { Solve problems of customers } \\
\text { Current customers use the product } \\
\text { Customer satisfaction }\end{array}$ \\
\hline 3. Business Success & Success on Business \\
& Make a big market share \\
\hline 4. Prepare for the future & Create a new market \\
& Create a new product line \\
& Develop a new technology \\
\hline
\end{tabular}

Source: Shenhar et al. (2001).

However, although there is a great deal of literature on the success of the project (Andersen et al., 1987; Atkinson, 1999; Cicmil \& Hodgson, 2006; Collins \& Baccarini, 2004) but there is no common consensus on a set of project success criteria. In addition, different perceptions on project success for different relating partners may also lead to ambiguity when determining the success criteria of the project Lim and Mohamed (1999).

\subsection{Success of the Project in Construction Industry}

Successful measurements of construction projects have been investigated including other factors beyond 'iron triangle' of time, cost and quality (Atkinson, 1999). Success should be measured on the basis of different relating partners such as the project owner, user, contractor, and management team. The participants in the project found success differently.

For example, project managers can view the success based on the end of the project over time, cost and quality predetermined (Lim \& Mohamed, 1999). Users can view success based on product features (ie buildings). Thus, success has been expanded to include successful products, in addition to successful projects (Baccarini, 1999). From the contractor's point of view, success can be measured on the basis of project profitability, on-time completion, safety, number of claims and trade efficiency (Sanvido, Grobler, Parfitt, Guvenis, \& Coyle, 1992).

Success is always subjective in terms of perception, and this is even more evident in the construction industry where there are different parties involved such as customers, architects, contractors, surveyors and engineers. Each participant will have their own perception of the success of the project and the criteria of success. From a traditional perspective, a construction project would be considered successful if the project handover was within the limit of three obstacles of project management (time, cost and quality) also meet the customer satisfaction. Although success is clearly about achieving the goal, there is still ambiguity in deciding whether a project is successful. It is clear that an industry like the construction industry, with the maturity of project management, can easily duplicate the success of its projects.

After reviewing the literature, Saqib, Farooqui, and Lodi (2008) categorized key success factors affecting construction projects into seven factors related to project management, purchasing, customer, design team, contractor, project manager, environment, organization. For elements related to project managers, the authors emphasize that the skills and characteristics, capabilities, commitment, experience, effectiveness of making decision greatly contributed to the success of the project.

On the other hand, in order to evaluate the success of the project in the construction sector, Chane and Lam (2002) conducted a comprehensive review of the literature related to the success criteria of the construction projects and issue two main categories: objective and subjective. Objective criteria refer to hard, tangible and measurable attributes such as time, cost and quality along with profitability, technical efficiency, perfection, ability to perform function, environmental sustainability, health and safety. On the other hand, subjective measures involve attributes such as satisfaction, no conflict, social image, professional image, and aesthetics. 


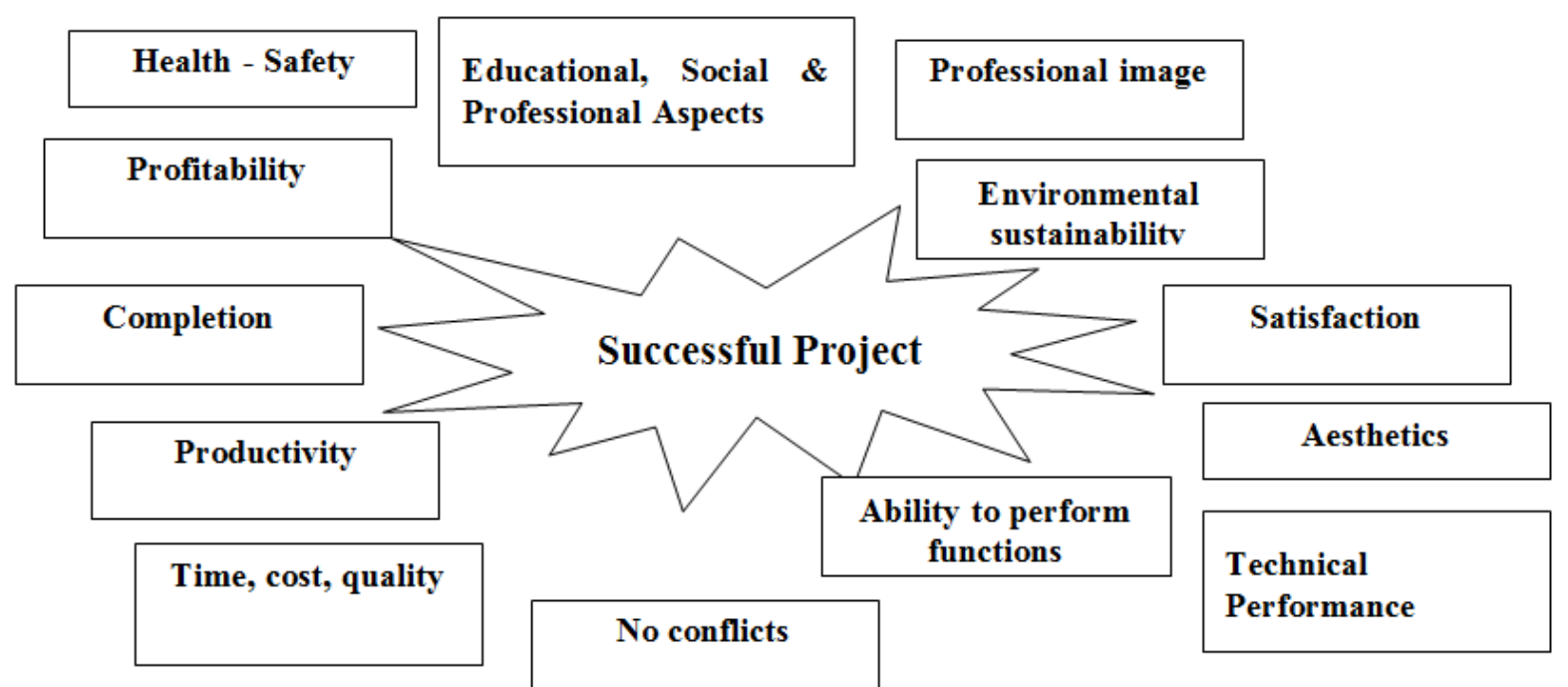

Source: Chane and Lam (2002).

Figure-2. Criteria for Project Success.

It is clear, however, that these success criteria are primarily related to the construction industry and may not be entirely consistent with the humanitarian sector where success factors and new criteria can be gathered as below:

\section{General Study of Impact of Leadership Competence of Project Managers on Project Success}

In the past, research in the field of project management focused on improving management effectiveness by using a variety of tools and techniques that ignore behavioral and communicative factors (Zimmerer \& Yasin, 1998). Cooke-Davies (2002) after providing a complete list of key project success factors, compensated for the omission of his human elements by recognizing that all success factors linking to a human factors that cannot be ignored. He concludes his study by saying that "The projects are transferred by the people themselves, not the processes and systems".

However, this point of view is not mentioned by many authors (Belout \& Gauvreau, 2004; Pintop \& Prescott, 1988) who wrote about the success factors of the project. Pinto and Slevin (1989) provide a classic list of the 10 successful elements of the project, which many authors have asked since they did not mention the contributions of project managers as a success factor.

After reviewing the literature on critical success factors, Turner and Muller (2005) have found that effective leadership is rarely identified as a key success factor in projects compared to in general management documents.

In 2007, the author tried to find a clear link between the project manager's leadership competence and the success of the project. This view was shared by Geoghegan and Dulewicz (2008) when they determined that a group of authors such as Hogan and Hogan (2002); Rees et al. (1996) recognizes the competences and essential characteristics of an effective project manager but fails to the link these skills and characteristics to the success of the project. In his work on the compilation of qualified project managers, Crawfordp (2007) discusses the lack of recognition of leadership in the list of success factors even if it appears constantly with high rank among the competences of the project manager.

Turner (1999) identified a strategy for successful implementation of projects. This seven-force model (based on the work of Morris (1988) and Morris and Hough (1987) contains a "human" force, representing people on the project and management, leadership, group working and labor relations. He recognized the need for leadership as part of the project's strategy or approach, leading to the successful implementation of the project.

When Lee-Kelley, Leong, and Loong (2003) begin to attempt to understand the fields of project management knowledge that are important to the success of the project, they find that the management style of the project manager create a great influence to the project manager's perception on the success of the project.

This leads them to conclude that there is a meaningful relationship between the perception of success and the leadership style of the leader because of the self-confidence and having confidence in the leader's self. It can affect a leader's ability to successfully transfer a project.

Rees et al. (1996) have identified six features of effective project managers and found that effective project managers are often more intelligent and able to solve problems better than normal project managers. These features are similar to the IQ (IQ) theory that Dulewicz and Higgs (2005) have 
developed as part of their leadership competence theory. Although Rees et al. (1996) identified six features, they do not provide any evidence that these features directly contribute to the success of the project.

Andersen et al. (1987) point out the importance of the personal characteristics of the project manager when selecting a project manager. However, they did not prove that personality traits also contributed to the success of the project.

Crawfordp (2007) defined project management competence as a combination of knowledge (skills), skills (ability to do tasks), and core personality traits (motivation, psychological state, self-concept) leads to great consequences.

He thinks that the competence of the project manager is very relevant to the success of the project. Crawford says leadership is the highest category of project management authorities, but it is not the highest ranking for project success.

Geoghegan and Dulewicz (2008) recognize that there is a relationship between the project manager's competence and the success of the project. In order to demonstrate the relationship between the project manager's competence and the success of the project, Geoghegan and Dulewicz (2008) used a questionnaire on leadership dimension (LDQ) and a questionnaire on success of the project (PSQ) to collect data from 52 project managers and project sponsors.

An analysis of PSQ shows three independent factors: usability, project distribution, and output value to the customer.

However, the value of the output to customers not related to the project leader, Geoghegan and Dulewicz (2008) mainly point out the correlation between usability, project distribution and project leadership.

They have found eight distinct leadership aspects (IQ size: critical analysis, EQ size: self-awareness, sensitivity, influence, motivation, MQ size: resource management, empowerment, development) are statistically related to the performance of the project, so they have demonstrated a relationship between the project manager's competence and the success of the project.

Müller and Turner (2010a) study the "record leadership competence of successful project managers", aimed at examining the leadership competence records of successful project managers in different types of projects.

Four hundred answers to the Leadership Development Question (LDQ) are used to describe project managers' intellectual, managerial, and emotional abilities for successful projects.

Differences by type of project are considered based on the classification of projects by type of application (engineering and construction, information technology and telecommunications, organizational change), complexity, importance and type of contract.

Results show high expression of a secondary IQ and 3 levels of EQ in successful management in all project types. Additional sizes vary by project type. The comparison was made with oriented, engaging and attractive, interesting leadership styles.

In short, perspectives on project manager leadership competence, and the success of the project have been studied quite clearly over the years, in which manager's remarkable leadership competence such as knowledge, skills, attitudes and other personal characteristics.

The document review shows the leadership competence of the project manager is complex but important for successful implementation of projects. No specific leadership competence framework is considered to be suitable for all project leaders in every project situation.

On the basis of literature, different competence used by different authors in the context have been considered but no combination of leadership competence can be considered the best for the success of the activities and complex projects in every situation.

Table-3. Summary of review of literature of impact of project manager leadership competence and the success of the project.

\begin{tabular}{|c|c|c|c|c|}
\hline Author & Research content & Method & Research results & $\begin{array}{l}\text { Limitations of the } \\
\text { study }\end{array}$ \\
\hline $\begin{array}{l}\text { Khan, } \\
\text { Long, and } \\
\text { Iqbal } \\
(2014)\end{array}$ & $\begin{array}{l}\text { Leadership } \\
\text { Competence: } \\
\text { Tools for Project } \\
\text { Success }\end{array}$ & $\begin{array}{l}\text { Theoretical research } \\
\text { through the data collected } \\
\text { from the database, the } \\
\text { articles have been } \\
\text { published. }\end{array}$ & $\begin{array}{l}\text { Leadership competence } \\
\text { has a positive impact on } \\
\text { the success of the } \\
\text { project that was } \\
\text { previously overlooked. } \\
\text { Project leadership } \\
\text { competence is similar } \\
\text { to leadership } \\
\text { competence in general } \\
\text { management. }\end{array}$ & $\begin{array}{l}\text { No quantitative } \\
\text { research, leadership } \\
\text { competence of project } \\
\text { managers in different } \\
\text { sectors and fields has } \\
\text { not yet been cleared. }\end{array}$ \\
\hline $\begin{array}{l}\text { Geoghegan } \\
\text { and } \\
\text { Dulewicz } \\
(2008)\end{array}$ & $\begin{array}{l}\text { Leadership } \\
\text { competence of } \\
\text { the project } \\
\text { manager }\end{array}$ & $\begin{array}{l}\text { The quantitative study } \\
\text { was based on a survey of } \\
52 \text { project managers } \\
\text { supported by a financial }\end{array}$ & $\begin{array}{lr}\text { Significant } & \text { correlation } \\
\text { between } & \text { project } \\
\text { manager } & \text { leadership } \\
\text { competence and project }\end{array}$ & $\begin{array}{l}\text { Confirmation results } \\
\text { when researching } \\
\text { projects in the financial } \\
\text { sector. }\end{array}$ \\
\hline
\end{tabular}




\begin{tabular}{|c|c|c|c|c|}
\hline Author & Research content & Method & Research results & $\begin{array}{c}\text { Limitations of the } \\
\text { study }\end{array}$ \\
\hline & $\begin{array}{l}\text { contributes to the } \\
\text { success of the } \\
\text { project. }\end{array}$ & $\begin{array}{l}\text { services providing firm } \\
\text { based in the UK based on } \\
\text { the Leadership Dimension } \\
\text { Questionnaire and the } \\
\text { success questionnaire of } \\
\text { the project }\end{array}$ & $\begin{array}{lr}\text { success, } & \text { specifically:: } 8 \\
\text { major } & \text { influencing } \\
\text { factors } & (\mathrm{MQ} \text { and IQ) } \\
\text { and } 2 & \text { medium affect } \\
\text { factors. } & \end{array}$ & $\begin{array}{l}\text { Small sample of } \\
\text { research. } \\
\text { Study in the UK }\end{array}$ \\
\hline $\begin{array}{l}\text { Müller and } \\
\text { Turner } \\
\text { (2010a) }\end{array}$ & $\begin{array}{l}\text { Attitude and } \\
\text { leadership } \\
\text { competence with } \\
\text { the success of the } \\
\text { project. }\end{array}$ & $\begin{array}{l}\text { Building on the } \\
\text { competence category of } \\
\text { leadership theories, this } \\
\text { study used } 400 \text { responses } \\
\text { to a global-based } \\
\text { questionnaire to identify } \\
\text { differences in attitudes and } \\
\text { leadership competencies of } \\
\text { the project manager and } \\
\text { its relationship to the } \\
\text { success of the project. }\end{array}$ & $\begin{array}{l}\text { Identify two types of } \\
\text { result erroneous, which } \\
\text { are deviations in the } \\
\text { results of the project } \\
\text { and differences in the } \\
\text { results of the business. }\end{array}$ & $\begin{array}{l}\text { The results show the } \\
\text { relative importance of } \\
\text { attitudes and leadership } \\
\text { competence for } \\
\text { different project } \\
\text { successes. } \\
\text { Study Global Leaders. }\end{array}$ \\
\hline $\begin{array}{l}\text { Müller and } \\
\text { Turner } \\
(2010 b)\end{array}$ & $\begin{array}{l}\text { Leadership } \\
\text { Competence } \\
\text { Profiles of } \\
\text { Successful } \\
\text { Project Managers }\end{array}$ & $\begin{array}{l}\text { Quantitative research with } \\
400 \text { answers to LDQ } \\
\text { leadership development } \\
\text { questions } r \text { describes } \\
\text { intellectual } \\
\text { emotional papacity, } \\
\text { managerial comper, and } \\
\text { Analyze leadership } \\
\text { competence in various } \\
\text { types of projects such as } \\
\text { technical projects, complex } \\
\text { projects, contracted } \\
\text { projects ... combined with } \\
\text { leading, engaging and } \\
\text { interesting leadership } \\
\text { styles. }\end{array}$ & $\begin{array}{l}\text { The leadership } \\
\text { competence profile of } \\
\text { the different project } \\
\text { managers varies by the } \\
\text { impact of IQ, EQ, MQ } \\
\text { to the success of the } \\
\text { project. } \\
\text { The comparison has } \\
\text { been made in } \\
\text { combination with } \\
\text { leading, engaging and } \\
\text { interesting leadership } \\
\text { styles. }\end{array}$ & $\begin{array}{l}\text { Integrated study of } \\
\text { leadership competence } \\
\text { and leadership styles } \\
\text { not specifically } \\
\text { distinguishing the } \\
\text { difference between } \\
\text { leadership style and } \\
\text { leadership competence. } \\
\text { Study in the USA }\end{array}$ \\
\hline
\end{tabular}

\section{References}

Abdul-Rahman, H., Rahim, F. A. M., Danuri, M. S. M., \& Low, W. W. (2007). A study on quality management during the preconstruction stage of design-and-build projects. Paper presented at the Proceedings: CME 25 Conference. Reading, 16-18 July.

Abdullah, W. M. W. (2010). Critical factors in project success: A study of public sector construction projects in Malaysia. Kuala Lumpur: University Malaya.

Al-Tmeemy, S. M., Abdul-Rahman, H., \& Harun, Z. (2011). Future criteria for success of building projects in Malaysia. International Journal of Project Management, 29(3), 337-348.

Andersen, E. S., Grude, K. V., Haug, T., \& Turner, J. R. (1987). Goal directed project management. London: Kogan Page/Coopers \& Lybrand.

Armstrong, M. (1996). A handbook of personnel management practice. London: Kogan Page Ltd.

Atkinson, R. (1999). Project management: Cost, time and quality, two best guesses and a phenomenon, it's time to accept other success criteria. International Journal of Project Management, 17(6), 337-342.

Baccarini, D. (1999). The logical framework method for the validity of leadership and performance determining critical success/failure factors in predictions? International Journal of Project Management, 14(3), 141-151.

Bakhsheshi, A. F., \& Nejad, S. R. (2011). Impact of project managers personalities. Paper presented at the 2nd International Conference on Construction and Project Management IPEDR. IACSIT Press, Singapore.

Bass, B. M. (1990). From transactional to transformational leadership: Learning to share the vision. Organizational Dynamics, 18(3), 19-31.

Belout, A., \& Gauvreau, C. (2004). Factors influencing project success: The impact of human resource management. International Journal of Project Management, 22(1), 1-11.

Boyatzis, R. E. (1982). The competent manager: A model for effective performance: John Wiley \& Sons.

Boyatziss, C. J. (1998). A collaborative assignment on the role of culture in child development and education. Teaching of Psychology, 25(3), 195-198.

Chan, A. P. C., Scott, D., \& Chan, A. P. L. (2004). Factors affecting the success of a construction project. Journal of Construction Engineering and Management, 130(1), 153-155.

Chane, S. D., \& Lam, E. W. M. (2002). Framework of success criteria for design/build projects. Journal of Management in Engineering, 18(3), 120-128. 
Chawla, S. K., Khanna, D., \& Chen, J. (2010). Are small business critical success factors same in different countries. SIES Journal of Management, 7(1), 1-12.

Cicmil, S., \& Hodgson, D. (2006). Making projects critical: An introduction. Making projects critical. New York: Palgrave Macmillan.

Collins, A., \& Baccarini, D. (2004). Project success-a survey. Journal of Construction Research, 5(2), 211 -231.

Cooke-Davies, T. (2002). The "real" success factors on projects. International Journal of Project Management, 20(3), 33-42.

Crawford, G. P. (2005). Flexible flat panel display technology (Vol. 3, pp. 1). West Sussex: Wiley.

Crawfordp, L. H. (2007). Developing the project management competence of individuals (4th ed.): Gower Handbook of Project Management.

Dulewicz, V., \& Higgs, M. (2005). Assessing leadership styles and organizational context. Journal of Management Psychology, 22(2), 105-123.

Freeman, M., \& Beale, P. (1992). Measuring project success. Project Management Journal, 23(1), 8-17.

Geoghegan, L., \& Dulewicz, V. (2008). Do project managers' leadership competencies contribute to project success. Project Management Journal, 39(4), 58-67.

Hogan, R., \& Hogan, J. (2002). Leadership and sociopolitical intelligence. LEA's organization and management series. Multiple intelligences and leadership (pp. 75-88). Lawrence Erlbaum Associates Publishers.

Jugdev, K., \& Muller, R. (2005). A retrospective look at our evolving understanding of project success. Project Management Journal, 36(4), 19-31.

Khan, S. R., Long, C. S., \& Iqbal, S. M. J. (2014). Leadership competence: Tools for project. Middle East Journal of Scientific Research, 19(10), 1280-1283.

Lee-Kelley, L., Leong, K., \& Loong. (2003). Turner's five functions of project-based management and situational leadership in IT services projects. International Journal of Project Management, 21(8), 583-591.

Lim, C. S., \& Mohamed, M. Z. (1999). Criteria of project success: An explanatory reexamination. International Journal of Project Management, $17(4), 243-248$.

Limsila, K., \& Ogunlana, S. O. (2008). Performance and leadership outcome correlates of leadership style and subordinate commitment. Engineering, Construction and Architectural Management, 15(2), 164-184.

Long, D. N., Ogunlana, S. O., \& Lan, D. T. (2004). A study on project success factors on large construction projects in Vietnam. Engineering, Construction and Architectural Management, 11(6), 404-413.

Moore, A. R., Cheng, M. I., \& Dainty, A. R. J. (2002). Competence, competency and competencies: Performance assessment in organizations. Work Study, 51(6), 314-319.

Morris, P. W. G. (1988). Managing project interfaces In D. I. Cleland \& W. R. King (Eds.), Project management handbook (2nd ed.). New York: Van Nostrand Reinhold.

Morris, P. W. G., \& Hough, G. H. (1987). The anatomy of major projects: A study of the reality of project management. Chichester, UK: Wiley.

Müller, R., \& Jugdev, K. (2012). Critical success factors in projects: Pinto, Slevin, and Prescott-the elucidation of project success. International Journal of Managing Projects in Business, 5(4), 757-775.

Müller, R., \& Turner, J. R. (2007a). The influence of project managers on project success criteria and project success by type of project. European Management Journal, 25(4), 298-309.

Müller, R., \& Turner, J. R. (2007b). Matching the project manager's leadership style to project type. International Journal of Project Management, 25(1), 21-32.

Müller, R., \& Turner, J. R. (2007b). The influence of project managers on project success criteria and project success by type of project. European Management Journal, 25(4), 289-309.

Müller, R., \& Turner, J. R. (2010a). Attitudes and leadership competences for project success. Baltic Journal of Management, $5(3), 307-329$

Müller, R., \& Turner, J. R. (2010b). Leadership competency profiles of successful project managers. International Journal of Project Management, 28(5), 437-448.

Munns, A. K., \& Bjeirmi, B. F. (1996). The role of project management in achieving project success. International Journal of Project Management, 14(2), 81-87.

Murphy, D. C., Baker, B. N., \& Fisher, D. (1974). Determinants of project success. Boston: Boston College, National Aeronautics and Space Administration.

Odusami, K. T. (2002). Perceptions of construction professionals concerning important on project success in four types of project. Paper presented at the 2nd Internation al Conference on Construction and Project Management IPEDR.

Parfitt, M. K., \& Sanvido, V. E. (1993). Checklist of critical success factors for building projects. Journal of Management in Engineering, 9(3), 243-249.

Pinto, J. K., \& Slevin, D. P. (1989). Critical success factors in R\&D projects. Research Technology Management, 39(4), 31-35.

Pintop, J. K., \& Prescott, J. E. (1988). Variations of critical success factors over the stages in the project life cycle. Journal of Management, 14(1), 5-18.

Rees, D., Turner, R., \& Tampoe, M. (1996). On being a manager and leader. UK: McGraw-Hill.

Sanvido, V., Grobler, F., Parfitt, K., Guvenis, M., \& Coyle, M. (1992). Critical success factors for construction projects. Journal of Construction Engineering and Management, $118(1), 94-111$.

Saqib, M., Farooqui, U. R., \& Lodi, H. S. (2008). Assessment of critical success factors for construction projects in Pakistan. Paper presented at the Proceeding of the First International Conference on Construction in Developing Countries (ICCIDC- I-2008), Karachi, Pakistan, August 4-5 2008.

Shenhar, A. J., Dvir, D., Levy, O., \& Maltz, A. C. (2001). Project success: A multidimensional strategic concept. Long Range Planning, 34(6), 699-725.

Shenhar, A. J., \& Wideman, R. M. (1996). Improving PM: linking success criteria to project type. Paper presented at the Project Management Institute, Symposium, Creating Canadian Advantage through Project Management, Calgary, Canada. 
Skipper, C. O., \& Bell, L. C. (2006a). Assessment with $360^{\circ}$ evaluations of leadership behaviour in construction project managers. Journal of Management in Engineering, 22(2), 75-80.

Songer, A., Chinowsky, P., \& Butler, C. (2006). Emotional intelligence and leadership behavior in construction executives. Journal of Management in Engineering, 22(3), 25-32.

Sotiriou, D., \& Wittmer, D. (2001). Influence methods of project managers: Perceptions of team members and project managers. Project Management Journal, 32(3), 12 - 20.

Spencer, L., \& Spencer, S. (1993). Competence at work: Models for superior performance. New York: Wiley.

Spencere, B. A. (1994). Models of organization and total quality management: A comparison and critical evaluation. Academy of Management Revier, 19(3), 446-45 1

Thamhain, H. J. (2003). Team leadership effectiveness in technology based project environments. Project.

Toor, S. R., \& Ofori, G. (2007). Ethics and authenticity of leadership in the construction industry. In T.C. Haupt and R. Milford (Eds.). Paper presented at the Proceedings of CIB World Building Congress on 'Construction for Development', 14-18 May, Cape Town, South Africa.

Toor, S. R., \& Ogunlana, S. O. (2008a). Critical COMs of success in large-scale construction projects: Evidence from Thailand construction industry. International Journal of Project Management, 26(4), 420-430.

Toors, S. U. R., \& Ofori, G. (2008). Leadership versus management: How they are different, and why. Leadership and Management in Engineering, 8(2), 61-71.

Turner, J. R. (1999). The handbook of project-based management: Improving the processes for achieving strategic objectives. London: McGraw-Hill.

Turner, J. R., \& Muller, R. (2005). The project manager's leadership style as a success factor on projects: A literature review. Project Management Journal, 36(2), 49-61.

Woodruffe, C. (1991). Competent by any other name. Personnel Management, 23(9), 30-33.

Zimmerer, T., \& Yasin, M. M. (1998). A leadership profile of American project managers. Project Management Journal, 29(1), 31-38. 